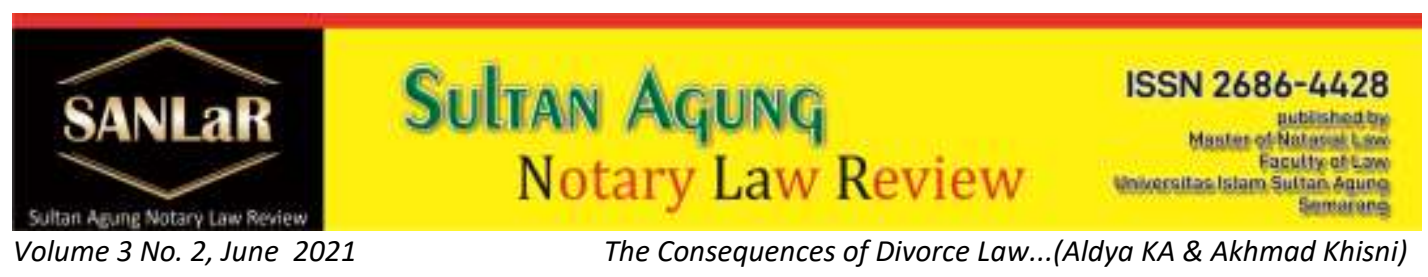

\title{
The Consequences of Divorce Law on Common Property under Marriage Law \& KHI
}

\author{
Aldya Khaira Almeyda*) and Akhmad Khisni**) \\ ${ }^{*}$ Faculty of Law, Universitas Islam Sultan Agung (UNISSULA) Semarang, E-mail: \\ aldyakhairaalmd@gmail.com \\ $\left.{ }^{* *}\right)$ Faculty of Law, Universitas Islam Sultan Agung (UNISSULA) Semarang, E-mail: \\ khisni@unissula.ac.id
}

\begin{abstract}
The distribution of joint assets according to the provisions of Article 37 of Act No. 1 of 1974 concerning Marriage is not clearly stipulated how much each husband or wife is divorced, either divorced or divorced. Article 37 paragraph (1) states that if a marriage breaks up due to divorce, the joint property is regulated according to their respective laws. In the explanation of Article 37 paragraph (1), it is emphasized that the respective laws are religious law, customary law and other laws related to the distribution of the joint property. In addition to Act No. 1 of 1974 concerning Marriage, the Compilation of Islamic Law also applies in Indonesia, which relates to the distribution of joint assets as regulated in Articles 96 and 97 of the Compilation of Islamic Law. Based on these things, the problems that will be examined in this research are: what are the legal consequences of settling disputes on joint property according to Marriage Act No. 1 of 1974 and $\mathrm{KHI}$, and what are the views of Islamic law regarding the distribution of joint assets after divorce, as well as the obstacles to the implementation of the distribution of joint assets in practice at the Salatiga Religious Court, Central Java Province.
\end{abstract}

Keywords: Divorce; Joint Assets; Marriage Law.

\section{Introduction}

A good family, happy physically and mentally is the dream of every human being. However, it is not easy to create a happy, lasting, safe and peaceful family throughout his life. Such a marriage is not possible if the parties who support the implementation of the marriage do not take care of each other and 
work together in fostering an eternal and eternal household. Besides that, marriage is also intended for a long time, where in principle the marriage will be carried out only once in a person's life.

When the household is in a state of harmony, generally the joint property acts as a complement to happiness. However, if the household experiences disharmony conditions, then the possibility of disputes and quarrels is quite large. Often, if the dispute cannot be resolved (out of control), the chances of the household condition reaching the peak of the dispute which leads to the condition of the dissolution of the marriage (broken marriage) are even greater.

If a divorce occurs, it is certain that it will have consequences for people who are related in one household, where in this case the legal consequences will be emphasized. The legal consequences of this divorce are of course also related to children and assets during marriage.

At the last level, joint property will become an arena of dispute. And it cannot be denied that the judiciary will also play a sufficient role in the dispute resolution process. The judiciary will be a medium for disputing husband and wife to express all their arguments, especially in order to realize the desire of each party to control the property.

Based on the explanation of the background above, the authors formulate the problem as follows:

a. What are the legal consequences of dispute resolution on joint assets according to the Marriage Act No. 1 of 1974 and the Compilation of Islamic Law?

b. What is the view of Islamic law regarding the distribution of joint assets after divorce?

c. What are the obstacles in implementing the distribution of joint assets in practice at the Salatiga Religious Court?

\section{Research Methods}

Research to support this writing is a normative research by examining library materials or secondary data. Normative research is a legal research conducted by examining library materials or secondary data. ${ }^{1}$ The specification of this research is descriptive analytical, the types and sources of data come from secondary data which includes primary legal materials, secondary legal materials, and tertiary

\footnotetext{
${ }^{1}$ Soerjono Soekanto dan Sri Mamudji, 2003, Penelitian Hukum Normatif: Suatu Tinjauan Singkat, Jakarta: PT RajaGrafindo Persada, p.13.
} 
legal materials. ${ }^{2}$ Based on the data sources and the method of normative juridical research as described above, the more appropriate data analysis used in this research is data analysis with a qualitative approach.

\section{Result and Discussion}

\subsection{Legal Consequences of Settlement of Disputes on Joint Assets According to the Marriage Act No. 1 of 1974 and the Compilation of Islamic Law}

The husband's authority or power is so great over the management of joint property. The husband is not responsible for the wife with regard to the management. He is also not required by his wife to give him calculations, including if the joint property together is finished / disbanded. However, the husband's great power is apparently limited by two things as follows: ${ }^{3}$

\section{a. Restricted by Law}

The husband's power in managing joint assets is limited by law. This is regulated in the Civil Code Article 124 paragraph 3.

Husbands and wives can also donate together. Article 124 paragraph 3 above provides an exception for grants which are functioned to pay attention to the position of children born from their marriage. This means that the grants made are for the benefit of the children and their future. In the form of a grant like this, the husband is allowed not to ask his wife for help.

The husband has limitations regarding grants to movable objects. The husband is not allowed to donate certain movable objects, unless it is agreed that the usufructuary rights are indeed awarded to the husband. ${ }^{4}$

b. Limited by the Agreement of Husband and Wife in the Agreement

Regarding property in marriage, the arrangement of joint assets between husband or wife can be carried out with the consent of both parties in their

\footnotetext{
2 Husein Umar, 2005, Metode Penelitian Untuk Makalah dan Tesis Bisnis, Jakarta: PT Raja Grafindo Persada, p.41.

${ }^{3}$ Soekanto dan Mamudji, Penelitian Hukum Normatif, Rajawali Press, Jakarta, 2001, p. 60-61.

${ }^{4}$ Felicitas Marcelina Waha, Penyelesaian Sengketa Atas Harta Perkawinan Setelah Bercerai, ,Lex et Societatis, Vol.I/No.1/Jan-Mrt/2013
} 
control, while regarding property, each husband and wife have the full right to carry out legal actions regarding their property ${ }^{5}$.

In Indonesia, there are two regulatory systems regarding marital property, which face each other in silence, meaning opposite each other, namely: Islamic Law and BW Law. ${ }^{6}$ The point here is that Islamic law considers the wealth of husband and wife to be separate from each other, the property belonging to each party (innate property) at the time the marriage begins, remains their respective property. Likewise, all their respective belongings which are obtained or obtained during the marriage (joint property), are not mixed but separated from each other. This is as stated in Article 86 of the Compilation of Islamic Law which reads:

a. Basically there is no mixing between the husband's property with the husband's property with the wife's property due to marriage.

b. The wife's property remains the wife's property and is fully controlled by her, as well as the husband's property remains the husband's right and is fully controlled by him.

Whereas in BW Law, on the contrary, considers it as the starting point if the husband and wife at the time of marriage do not enter into a separation agreement between them, then the result of the marriage is the mixing of the wealth of the husband and wife into one wealth belonging to the two of them together and their share each in the common wealth is half. ${ }^{7}$

\subsection{Views of Islamic Law Regarding the Distribution of Joint Assets Post Divorce}

Basically, Islamic law does not contain any mixing of assets in a marriage between husband and wife (joint assets). The concept of treasure joint assets originally came from the customs that developed in Indonesia. This concept is then supported by Islamic law and positive law that applies in Indonesia. ${ }^{8}$ The wife's assets remain the property of the wife and are fully controlled by her, as well as the husband's assets become the property of the husband and are fully controlled by the husband. Because wealth is a basic need, it is not easy to

\footnotetext{
${ }^{5}$ Ibid.

6 Martiman Prodjohamidjojo, “Indonesian Marriage Law”, Indonesia Legal Center Publishing, 2002, p. 37.

7 Martiman Prodjohamidjojo, "Hukum Perkawinan Indonesia", Indonesia Legal Center Publishing, 2002, p. 85.

${ }^{8}$ Wirjono Prodjodikoro, "Hukum Perkawinan di Indonesia", Alumni, Bandung, 1981, p.10
} 
combine it, so to own and control assets is an absolute obligation for each husband and wife $^{9}$.

In Islam there are no specific rules on how to divide the wealth of joint assets. Islam only provides general guidelines in solving common problems, including the distribution of assets depending on the agreement of husband and wife. This agreement in the Qur'an is referred to as "ash-Shulhu" which is an agreement to make peace between the two parties (husband and wife) after they have a dispute ${ }^{10}$.

Likewise, in the distribution of assets, one of the two parties or both sometimes have to give up their rights in order to reach an agreement ${ }^{11}$.

In the KHI (Compilation of Islamic Law) in the Religious Courts, namely Article 97 which states that: "Each widower and widower are entitled to one-half of the joint property as long as it is not specified otherwise in the marriage agreement." Where there is a necessity to divide equally, that is, each of them gets $50 \%$, as explained in the $\mathrm{KHI}$ above, it turns out that there is no evidence that can be justified, so that the correct income in the distribution of assets is going back to the agreement between husband and wife. These provisions, in line with Article 37 of Act No. 1 of 1974 concerning Marriage and the Jurisprudence of the Supreme Court of the Republic of Indonesia No. 424.K/Sip/1959 dated December 9, 1959 which contains a legal abstract that in the event of a divorce ${ }^{12}$.

Thus, the distribution of joint assets or joint assets can be reached through a religious court decision or through deliberation. In the settlement of the distribution of joint property through this deliberation, they may agree that the ex-husband gets one-third of the joint property, while the ex-wife gets twothirds. Or conversely, the ex-wife gets one-third, while the ex-husband gets

${ }^{9}$ Deen, Thaufiq., Ong Argo Victoria \& Sumain. (2018). Public Notary Services In Malaysia. JURNAL AKTA: Vol. 5, No. 4, 1017-1026. Retrieved from http://jurnal.unissula.ac.id/index.php/akta/article/view/4135

${ }^{10}$ Farhati, Dewi \& Akhmad Khisni. (2018). Legal Review Of Implementation Endowments Authority Relating To The Under Hand Agreement Made By Waqif (Case Study In Kua Wonosalam, Demak). JURNAL AKTA: Vol. 5, No. 3. Retrieved from http://jurnal.unissula.ac.id/index.php/akta/article/view/3256/2392

${ }_{11}$ Happy Susanto, Pembagian Harta Bersama Gono Gini Saat Terjadi Perceraian. Trasmedia Pustaka, Jakarta: 2008, p.10

12 Rachmawati, Noor., \& Hanim, Lathifah. (2018). Notary Role in The Establishment of Foreign Investment Limited Company Based on The Act No. 25 Of 2007 on Investment in Semarang. JURNAL AKTA: Vol. 5, No. 4, 965-974. Retrieved from http://jurnal.unissula.ac.id/index.php/akta/article/view/3939 
two-thirds. The important thing is that the percentage of each share is produced on the basis of deliberation, consensus and peace, and there is no element of coercion. The Prophet Muhammad SAW said: "Peace is permissible between Muslims, except peace which forbids the lawful or makes lawful the unlawful" (HR. Al-Hakim, Abu Daud, Ibn Hibban, and At. Tirmidhi).

\subsection{Barriers to the Implementation of Shared Assets in Practice at the Salatiga Religious Court}

The obstacles to the implementation of the distribution of joint assets in practice in the Salatiga Religious Court itself are numerous. Based on the results of the author's interview with the Salatiga Religious Court Judge, Drs. Syamsuri, MH on February 10, 2021, the obstacles experienced in the implementation of the distribution of joint assets in practice at the Salatiga Religious Court include ${ }^{13}$ :

a. If one of the parties, both husband and wife, does not want to sell the joint property, for example a house when it is to be cashed, both husband and wife must both sign to approve the sale of the house, if one of the parties refuses, or does not want to sign, then The house cannot be sold, so it cannot be immediately divided into ownership of the joint property.

b. If one of the parties, both husband and wife, has remarried before the joint property is divided, the process will be a bit complicated for the Religious Courts to find out/determine some of their respective rights in the process of distributing Joint assets.

\section{Closing}

Act No. 1 of 1974 Article 35 has regulated the distribution of joint assets. Then, according to the Compilation of Islamic Law, the settlement of disputes between husband and wife is submitted to the Religious Courts. The judge may decide that the distribution of joint property which is proven to be divided between husband and wife gets the same share, which is one-half of the share for the wife. If there is a dispute between husband or wife regarding joint property, the property is divided in two according to the value of the joint property. Then if the joint property is sold by one of the parties before the court's decision, the judge decides to take into account the joint property sold plus the remaining joint property then divided by two. Judging from Islamic law that property in marriage is divided into two, namely separate property and joint property or sharia property. Meanwhile, according to the Marriage Law, joint property is property

13 Harjanto, Fery., \& Gunarto. (2018). Effects Of Creation Deed of Sale and Purchase of Land Which Does Not Match Procedure of Making Land Deeds. JURNAL AKTA: Vol. 5, No. 4, 857-864. Retrieved from http://jurnal.unissula.ac.id/index.php/akta/article/view/3718 
acquired during a marriage by husband and wife. That husband and wife are equally entitled to use or use joint assets with the mutual consent of both parties. Thus, in principle, joint property is regulated jointly in everything there must be a mutual agreement. According to the Marriage Law, in the event of a divorce, the position of joint property is regulated according to their respective laws. This means that the division of joint property in the event of a divorce submits the distribution according to the law that lives in the community where the marriage and household are located.

\section{References}

Journal:

[1] Deen, Thaufiq., Ong Argo Victoria \& Sumain. (2018). Public Notary Services In Malaysia. JURNAL AKTA: Vol. 5, No. 4, 1017-1026. Retrieved from http://jurnal.unissula.ac.id/index.php/akta/article/view/4135

[2] Farhati, Dewi \& Akhmad Khisni. (2018). Legal Review Of Implementation Endowments Authority Relating To The Under Hand Agreement Made By Waqif (Case Study In Kua Wonosalam, Demak). JURNAL AKTA: Vol. 5, No. 3. Retrieved from http://jurnal.unissula.ac.id/index.php/akta/article/view/3256/2392

[3] Felicitas Marcelina Waha, Penyelesaian Sengketa Atas Harta Perkawinan Setelah Bercerai, Lex et Societatis, Vol.I/No.1/Jan-Mrt/2013

[4] Harjanto, Fery., \& Gunarto. (2018). Effects Of Creation Deed of Sale and Purchase of Land Which Does Not Match Procedure of Making Land Deeds. JURNAL AKTA: Vol. 5, No. 4, 857-864. Retrieved from http://jurnal.unissula.ac.id/index.php/akta/article/view/3718

[5] Rachmawati, Noor., \& Hanim, Lathifah. (2018). Notary Role in The Establishment of Foreign Investment Limited Company Based on The Act No. 25 Of 2007 on Investment in Semarang. JURNAL AKTA: Vol. 5, No. 4, 965-974. Retrieved from http://jurnal.unissula.ac.id/index.php/akta/article/view/3939

Books:

[1] Happy Susanto, 2008, Pembagian Harta Bersama Gono Gini Saat Terjadi Perceraian, Trasmedia Pustaka, Jakarta.

[2] Husein Umar, 2005, Metode Penelitian Untuk Makalah dan Tesis Bisnis, Jakarta: PT Raja Grafindo Persada.

[3] Martiman Prodjohamidjojo, 2002, Hukum Perkawinan Indonesia, Indonesia Legal Center Publishing.

[4] Soerjono Soekanto, 1986, Pengantar Penelitian Hukum, UI Press, Jakarta. 
[5] Soerjono Soekanto dan Sri Mamudji, 2003, Penelitian Hukum Normatif: Suatu Tinjauan Singkat, Jakarta: PT RajaGrafindo Persada.

[6] Wirjono Prodjodikoro, 1981, Hukum Perkawinan di Indonesia, Alumni, Bandung.

Regulations:

[1] Act No. 1 of 1974 concerning Marriage

[2] Civil Code

[3] Islamic Law Book 